\title{
BINDING OF RADIOIODINATED HUMAN PLACENTAL LACTOGEN TO BUFFALO CORPUS LUTEUM IN VITRO
}

\author{
S. B. MOODBIDRI, A. R. SHETH AND SHANTA S. RAO \\ Institute for Research in Reproduction (ICMR), \\ Parel, Bombay 12, India
}

(Received 7th November 1972)

\begin{abstract}
Summary. Binding of human placental $\left[{ }^{125} \mathrm{I}\right]$ lactogen to homogenates of the buffalo GL was studied. Differential centrifugation studies revealed the existence of hormone-binding components in fractions of the CL homogenate sedimenting at $800 \mathrm{~g}, 10,000 \mathrm{~g}$ and $100,000 \mathrm{~g}$. The binding was affected by incubation time and hormone concentration. The hormone-binding components were heat-labile and susceptible to proteolytic enzymes.
\end{abstract}

\section{INTRODUCTION}

The earliest event in the mechanism of action of protein hormone seems to be the binding of hormones to receptors in or on the cells of target tissues. A number of studies with HCG (Espeland, Naftolin \& Paulsen, 1968; Eshkol \& Lunenfeld, 1968; Figarova, Presl, Wagner \& Horsky, 1970; Catt, Dufau \& Tsuruhara 1971; Danzo, Midgley \& Kleinsmith, 1972; Leidenberger \& Reichert, 1972), LH (de Kretser, Catt, Burger \& Smith, 1969; de Kretser, Catt \& Paulsen, 1971; Lee \& Ryan, 1971; Moudgal, Moyle \& Greep, 1971; Caulson, Liu, Morris \& Gorski, 1972), FSH (Means \& Vaitukaitis, 1972), prolactin (Sheth, Midgley \& Niswender, 1972) and other protein hormones (Pastan, Roth \& Macchia, 1966; Lefkowitz, Roth, Pricer \& Pastan, 1970; Rodbell, Krans, Pohl $\&$ Birnbaumer, 1971) have now been reported which indicate that the use of labelled hormones allows direct study of the possible presence of receptors within the tissue.

The aim of the present study was to demonstrate and characterize the interaction between human placental lactogen (HPL) and the components of the CL of the Indian water buffalo, in an in-vitro system. Human placental lactogen was used since it has been shown to be similar to corresponding placental proteins from a number of other mammalian species, including cattle (Gusdon, Leake, Van Dyke \& Atkins, 1970).

\section{MATERIALS AND METHODS}

Buffalo ovaries, bearing CL in various stages of development, were obtained from the local slaughter house. The CL were separated from the ovaries and the tissues were stored at $-20^{\circ} \mathrm{C}$ until use. For the experiments, the tissues were 
homogenized in the cold in 0.5 to $1.0 \mathrm{ml}$ phosphate-buffered saline (PBS; 0.01 M-phosphate buffer, $\mathrm{pH} 7 \cdot 0$, with $0.14 \mathrm{M}-\mathrm{NaCl}$ ) in an all-glass homogenizer mechanically driven at very slow speed, and made up to a $10 \%$ tissue concentration. The subcellular fractions were isolated by differential centrifugation. A $10 \%$ tissue homogenate was prepared in $0.25 \mathrm{M}$-sucrose and centrifuged at $800 \mathrm{~g}$ for $10 \mathrm{~min}$ at $4^{\circ} \mathrm{C}$ to yield the nuclear-membranous pellet. The supernatant was centrifuged for $60 \mathrm{~min}$ at $10,000 \mathrm{~g}$, using a Spinco centrifuge model $65 \mathrm{~L}-\mathrm{B}$ to obtain the mitochondrial pellet. The microsomal pellet was obtained by centrifuging the $10,000 \mathrm{~g}$ supernatant at $100,000 \mathrm{~g}$ for $60 \mathrm{~min}$. All the individual pellets were resuspended in PBS to the original volume of the homogenate. The protein content of the tissue was determined according to the method of Lowry, Rosebrough, Farr \& Randall (1951), using bovine serum albumin as the standard.

The method of Greenwood, Hunter \& Glover (1963) as modified by Midgley (1966) was used to iodinate HPL. After termination of the reaction, the iodinated hormone was separated from the free iodine by fractionating the mixture on a column $(1 \mathrm{~cm} \times 20 \mathrm{~cm})$ of Sephadex G-75. A fraction from the descending leg of the protein peak was used for the studies. The specific activity of the labelled hormone was $100 \mu \mathrm{Ci} / \mu \mathrm{g}$.

\section{Binding procedure}

The following method of binding was employed in our assay system. Aliquots of whole homogenates or suspensions of subcellular fractions were incubated with $\left[{ }^{125} \mathrm{I}\right] \mathrm{HPL}$ in a final volume of $0.5 \mathrm{ml}$, made up with PBS containing $1 \%$ egg white at $37^{\circ} \mathrm{C}$. At the end of the incubation period, the contents of each tube were made up to $2.5 \mathrm{ml}$ with egg white-PBS when using glass tubes, and to $10.5 \mathrm{ml}$ when using nitrocellulose tubes (for high-speed centrifugation). The supernatant in each case was discarded. The pellets were suspended in PBS to the original volumes, recentrifuged, and the supernatants were discarded. This washing procedure was repeated once. Pilot studies indicated that two washes were sufficient to remove the unbound radioactivity.

The amount of radioactive hormone bound to the pellet was determined by $\gamma$-ray spectroscopy. The tubes containing PBS with $1 \%$ egg white served as controls for determining non-specific adherence of radioactive material to the tubes. All the determinations were carried out at least in duplicate.

The results were expressed in terms of the percentage of total counts added which were bound to the pellet.

\section{RESULTS}

The CL showed higher binding $(8.73 \%)$ in the 800 -g pellet compared to that $(4.25 \%)$ of the non-luteal portion of the ovarian tissue (Table 1$)$.

Text-figure 1 illustrates the uptake of $\left[{ }^{125} \mathrm{I}\right] \mathrm{HPL}$ by the $800-\mathrm{g}$ pellet in the presence of unlabelled hormones. While there was no inhibition with bovine FSH or LH at a concentration of $80.0 \mathrm{ng}$ unlabelled HPL, the binding of the labelled hormone was totally inhibited. The large amount of cold HPL required to displace labelled HPL may suggest that the binding of HPL to specific sites 
Binding of HPL to buffalo corpus luteum

Table 1. Binding of $\left[{ }^{125} \mathrm{I}\right] \mathrm{HPL}$ to buffalo corpus luteum and ovary

\begin{tabular}{l|c}
\hline \multicolumn{1}{c|}{ Tissue } & Percentage of total $\left[^{125}\right.$ I]HPL bound \\
\hline Corpus luteum & $8 \cdot 73 \pm 0.03^{*}$ \\
Ovary & $4 \cdot 25 \pm 0.26$ \\
\hline
\end{tabular}

Aliquots $(0 \cdot 2 \mathrm{ml})$ of $10 \%$ homogenates of fully developed CL and of ovarian tissue were incubated with $3.0 \mathrm{ng}$ of $\left[{ }^{125} \mathrm{I}\right] \mathrm{HPL}$ at $37^{\circ} \mathrm{C}$ for $60 \mathrm{~min}$.

* Mean of three observations \pm S.E.

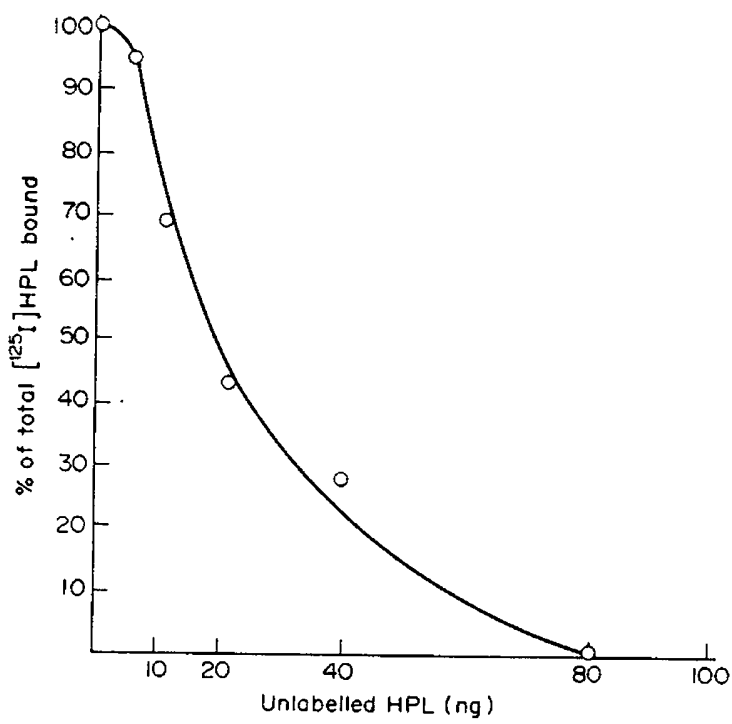

TEXT-FIG. 1. Effect of unlabelled hormones on binding of $\left.{ }^{125} \mathrm{I}\right] \mathrm{HPL}$ to $800 \mathrm{-g}$ pellet of homogenized buffalo corpus luteum. Aliquots $(0.2 \mathrm{ml})$ of suspension of the $800-\mathrm{g}$ pellet were incubated with $3.0 \mathrm{ng}\left[{ }^{125} \mathrm{I}\right] \mathrm{HPL}$ in the presence of 5.0 to $80.0 \mathrm{ng}$ of unlabelled HPL or 5.0 to $160.0 \mathrm{ng}$ of bovine FSH or LH at $37^{\circ} \mathrm{C}$ for $60 \mathrm{~min}$.

Table 2. Subcellular localization of HPL-binding components of buffalo corpus luteum

\begin{tabular}{l|c}
\hline \multicolumn{1}{c|}{ Sedimenting fraction } & $\begin{array}{c}\text { Percentage of total } \\
{[12 \mathrm{~s} I] \text { HPL bound }}\end{array}$ \\
\hline 800-g pellet (nuclear-membraneous) & $6 \cdot 42^{*}$ \\
$10,000-\mathrm{g}$ pellet (mitochondrial) & $9 \cdot 60$ \\
$100,000-\mathrm{g}$ pellet (microsomal) & 13.96 \\
\hline
\end{tabular}

Aliquots $(0.6 \mathrm{ml})$ of a $10 \%$ homogenate of CL were incubated with $9.0 \mathrm{ng}$ [ $\left.{ }^{125} \mathrm{I}\right] \mathrm{HPL}$ in a final volume of $1.5 \mathrm{ml}$ at $37^{\circ} \mathrm{C}$ for $60 \mathrm{~min}$. After incubation, the tubes were centrifuged to get the $800-\mathrm{g}$ pellet. The supernatant was diluted to $10.5 \mathrm{ml}$ with $0.25 \mathrm{M}$-sucrose and centrifuged in a Spinco model L-65 B using a fixed angle rotor to obtain $10,000-g$ (mitochondrial) and 100,000-g (microsomal) pellets.

* Mean of two observations. 


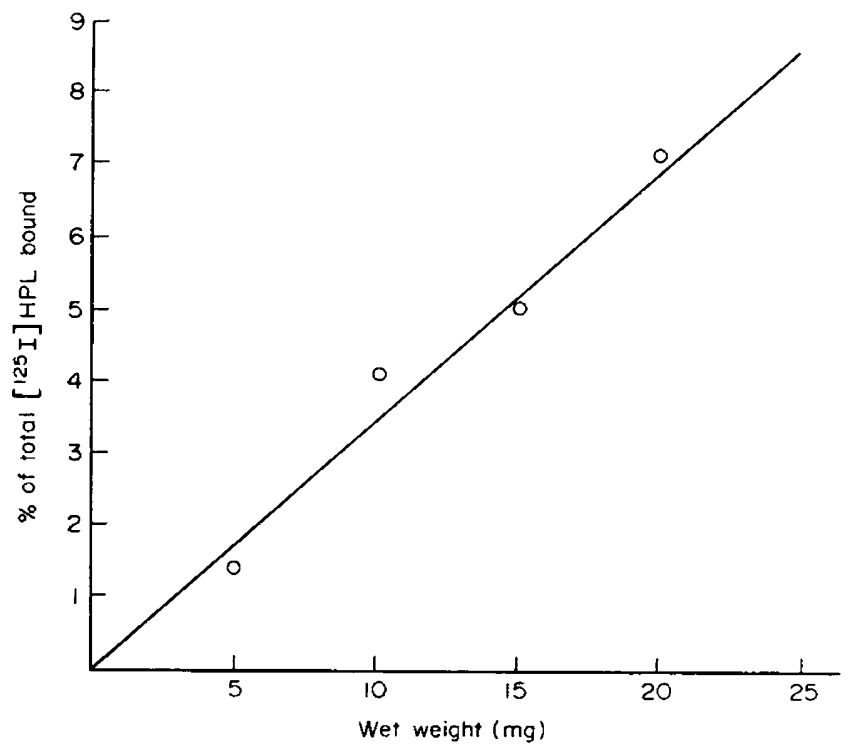

Text-rig. 2. Effect of tissue concentration. Aliquots $(0.05$ to $0.2 \mathrm{ml})$ of a $10 \%$ homogenate of buffalo corpora lutea, representing 5.0 to $20.0 \mathrm{mg}$ of the wet tissue, were incubated with $3.0 \mathrm{ng}\left[{ }^{125} \mathrm{I}\right] \mathrm{HPL}$ in a final volume of $0.5 \mathrm{ml}$ at $37^{\circ} \mathrm{C}$ for $60 \mathrm{~min}$. The tubes were centrifuged to obtain the $800-g$ pellet.

may represent a smaller percentage of the total uptake than that to nonspecific sites.

The results of differential centrifugation studies designed to ascertain whether the 800-g supernatant contained hormone-binding components

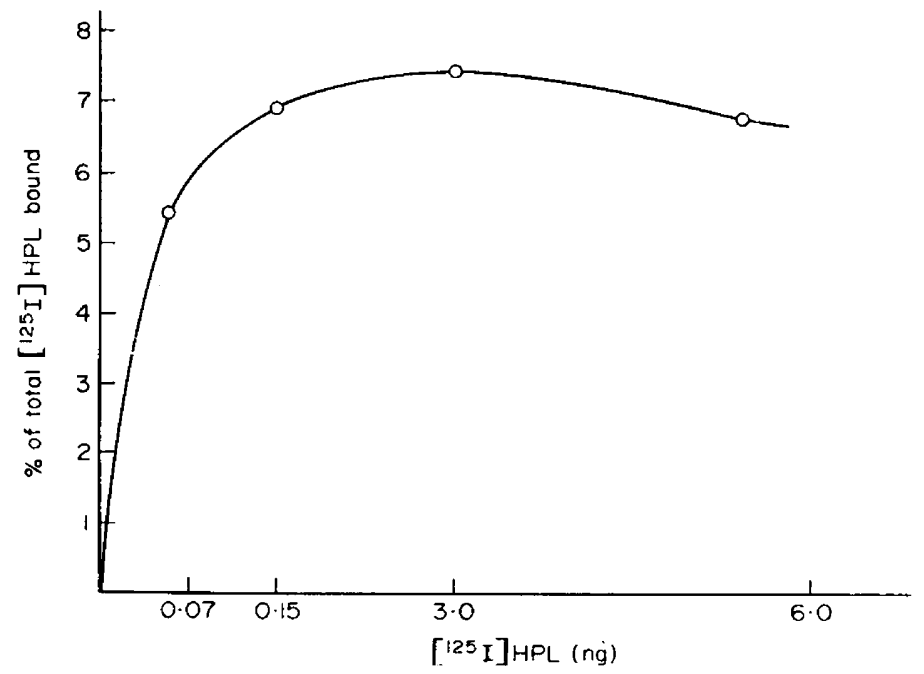

Text-FIG. 3. Effect of hormone concentration. Aliquots $(0.2 \mathrm{ml})$ of a $10 \%$ homogenate of buffalo corpora lutea were incubated with increasing amounts of $\left.{ }^{125} \mathrm{I}\right] \mathrm{HPL}$ ranging from $0.075 \mathrm{ng}$ to $6.0 \mathrm{ng}$ at $37^{\circ} \mathrm{C}$ for $60 \mathrm{~min}$. The tubes were centrifuged to obtain the $800-\mathrm{g}$ pellet at the end of the incubation period. 


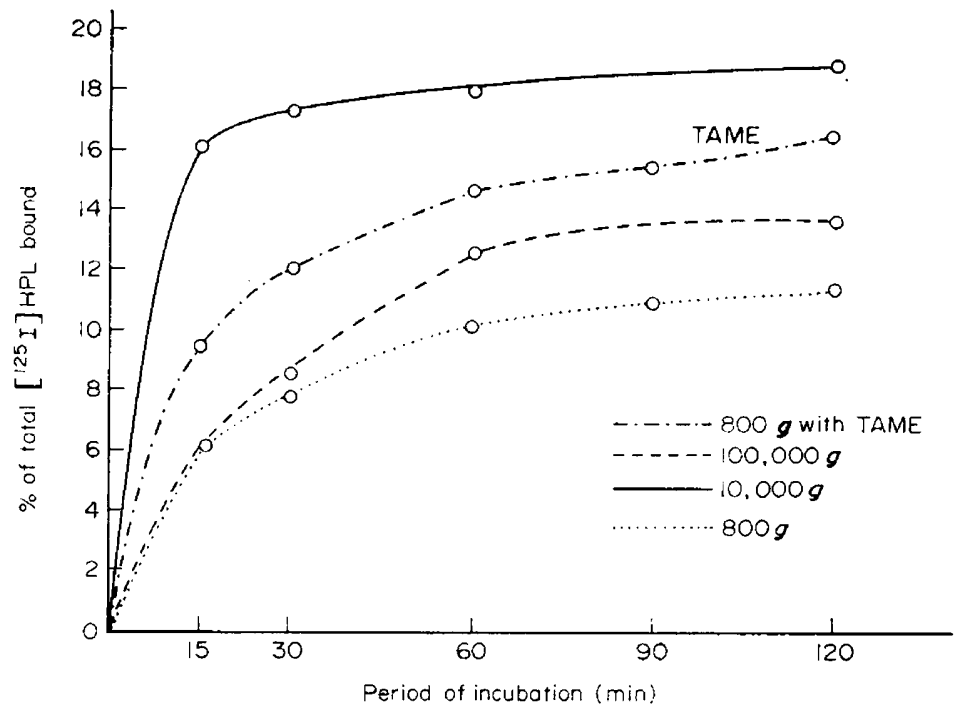

TeXT-FIG. 4. Effect of incubation time. Aliquots $(0.2 \mathrm{ml})$ of suspensions of buffalo corpus luteum homogenates were incubated at $37^{\circ} \mathrm{C}$ for periods ranging from 15 to 120 min with $3.0 \mathrm{ng}\left[{ }^{125} \mathrm{I}\right] \mathrm{HPL}$. A parallel series of tubes which also contained $1.0 \mathrm{mg}$ toluene sulphonyl methyl ester (TAME) per tube were incubated for the $800-g$ pellet.

revealed that mitochondrial and microsomal fractions also showed binding which was higher than that of the 800-g pellet (Table 2). However, a considerable amount of radioactivity remained in the cytosol.

Subsequent experiments carried out to study the effect of tissue and hormone concentration on binding, showed that the percentage of hormone bound to the $800-g$ pellet was directly proportional to the amount of tissue used (Text-fig. 2) as well as the concentration of the labelled hormone (Text-fig. 3). There was a slight decrease in the amount of bound hormone, however, when the concentration of the labelled hormone exceeded $3 \cdot 0 \mathrm{ng}$.

Text-figure 4 depicts the effect of incubation time on the binding of the

Table 3. Effect of heat on binding of $\left[{ }^{125} \mathrm{I}\right]$ HPL to buffalo corpora lutea

\begin{tabular}{|c|c|c|c|}
\hline \multirow{2}{*}{$\begin{array}{c}\text { Temperature } \\
\left({ }^{\circ} \mathrm{C}\right)\end{array}$} & \multicolumn{3}{|c|}{ Percentage of total $\left[{ }^{125} I\right] H P L$ bound by } \\
\hline & $\begin{array}{l}800-g \\
\text { pellet }\end{array}$ & $\begin{array}{c}10,000-g \\
\text { pellet }\end{array}$ & $\begin{array}{c}100,000-g \\
\text { pellet }\end{array}$ \\
\hline $\begin{array}{r}37 \\
60 \\
100\end{array}$ & $\begin{array}{c}12 \cdot 67^{*} \\
9 \cdot 13 \\
6 \cdot 24\end{array}$ & $\begin{array}{c}19.64 \dagger \\
14.91 \\
7.16\end{array}$ & $\begin{array}{c}15 \cdot 81 \dagger \\
13 \cdot 55 \\
8 \cdot 12\end{array}$ \\
\hline
\end{tabular}

Aliquots $(0.2 \mathrm{ml})$ of the suspensions were heated for $10 \mathrm{~min}$ at $37^{\circ} \mathrm{C}, 60^{\circ} \mathrm{C}$ and $100^{\circ} \mathrm{C}$, the tubes were brought to room temperature and then incubated with $\left[{ }^{125} \mathrm{I}\right] \mathrm{HPL}$ at $37^{\circ} \mathrm{C}$ for $60 \mathrm{~min}$.

* Mean of two observations.

$\uparrow$ Mean of three observations. 
hormone to three pellets. An initial rapid increase in binding was observed, which reached a more or less steady level after incubation for $30 \mathrm{~min}$.

Exposure to heat at $60^{\circ} \mathrm{C}$ and $100^{\circ} \mathrm{C}$ for $10 \mathrm{~min}$ before incubation with the labelled hormone reduced the hormone-binding capacity of all the three pellets (Table 3 ).

Incubation with enzymes like trypsin, chymotrypsin and proteinase greatly reduced the capacity of all the pellets to bind the radioiodinated hormone, but no appreciable change was observed with collagenase (Table 4). Text-figure 4 shows that, in the presence of the proteolytic enzyme inhibitor, toluene sulphonyl methyl ester, the binding activity of the $800-\mathrm{g}$ pellet was increased at all the time intervals studied.

Table 4. Effect of enzyme digestion on binding of $\left[{ }^{125} \mathrm{I}\right] \mathrm{HPL}$ to buffalo corpora lutea

\begin{tabular}{l|c|c|c}
\hline \multirow{2}{*}{$\quad$ Enzyme } & \multicolumn{3}{|c}{ Percentage of total $\left[^{125} I\right] H P L$ bound by } \\
\cline { 2 - 4 } & $\begin{array}{c}800-\mathrm{g} \\
\text { pellet }\end{array}$ & $\begin{array}{c}10,000-\mathrm{g} \\
\text { pellet }\end{array}$ & $\begin{array}{c}100,000-\mathrm{g} \\
\text { pellet }\end{array}$ \\
\hline None & $7 \cdot 22 \pm 0.27^{*}$ & $19.97 \dagger$ & $13 \cdot 17 \dagger$ \\
Collagenase & $7 \cdot 61 \pm 0.22$ & 20.30 & $13 \cdot 40$ \\
Proteinase & $1.02 \pm 0.02$ & 14.78 & 3.86 \\
Trypsin & $2 \cdot 22 \pm 0.22$ & 15.10 & 6.82 \\
Chymotrypsin & $2 \cdot 61 \pm 0.60$ & - & - \\
\hline
\end{tabular}

Aliquots $(0.2 \mathrm{ml})$ of suspensions were incubated at $37^{\circ} \mathrm{C}$ for $30 \mathrm{~min}$ with $0.25 \mathrm{ml}$ of different enzyme solutions containing $250 \mu \mathrm{g}$ of the enzymes. The tubes were centrifuged, the pellets washed with PBS and resuspended in $0.4 \mathrm{ml}$ PBS containing $1 \%$ egg white. After $\left[{ }^{125} \mathrm{I}\right] \mathrm{HPL}$ was added, the tubes were incubated at $37^{\circ} \mathrm{C}$ for $60 \mathrm{~min}$.

* Mean of three observations \pm S.E.

$\uparrow$ Mean of two observations.

\section{DISGUSSION}

It is generally assumed that protein hormones do not enter the target cell but interact with the cell membrane. However, recent studies with HCG (Danzo et al., 1972), LH (de Kretser et al., 1971; Caulson et al., 1972), FSH (Means \& Vaitukaitis, 1972) and prolactin (Sheth et al., 1972) suggest that the hormone may bind with intracellular components (nuclei, mitochondria and microsomes) as well as the cell membrane.

In our studies with $\left[{ }^{125} \mathrm{I}\right] \mathrm{HPL}$, after fractionation of the homogenate of buffalo CL by differential centrifugation, the label was found to be associated with the 800-g nuclear-membranous pellet and the 10,000-g mitochondrial pellet, as well as with the $100,000-\mathrm{g}$ microsomal pellet. This distribution of label could indicate the presence of binding components in these subcellular fractions, but the possibility of contamination of one fraction by another during homogenization cannot be ruled out.

The susceptibility of the binding components to proteolytic enzymes is indicative of their proteinaceous nature. The binding components were heat-labile 
and the binding could be affected by incubation time and hormone and tissue concentrations.

Josimovich \& Brande (1964) have speculated that, in primates, the placental peptide hormones may induce steroidogenesis in the ovary and placenta. They have shown HPL to be luteotrophic in pseudopregnant rats but such an effect has not been observed in pregnant women (Saxena, 1971). Whether an HPLlike placental protein in cattle, either alone or in combination with other hormone(s), will have any luteotrophic function is not known.

Our observations on the binding of labelled HPL to buffalo CL in themselves do not provide evidence for a physiological interaction of the hormone with tissue. Preliminary studies (S. B. Moodbidri, A. R. Sheth and S. S. Rao, unpublished data) have indicated that HPL stimulates adenyl cyclase in buffalo CL. It remains to be ascertained, however, whether the hormone will have a steroidogenic effect in the tissue. The possibility of developing a radioligand-receptor assay for HPL is also being examined.

\section{ACKNOWLEDGMENTS}

The authors are grateful to Dr U. C. Rane and Dr B. S. Mathur of the Bandra Slaughter House of the Bombay Municipal Corporation for their help in collecting the tissues used in these studies.

Human placental lactogen used for the studies was a gift from NIAMD of the National Institutes of Health, Bethesda, U.S.A. Bovine FSH and LH were kindly supplied by Dr L. E. Reichert, Jr. Trypsin, chymotrypsin and collagenase were obtained from Worthington Biochemical Corporation, U.S.A., and proteinase was obtained from Koch-Light Laboratories, U.K. Toluene sulphonyl methyl ester was supplied by Mann Research Laboratories Inc., U.S.A. Carrier-free ${ }^{125}$ Iodine was obtained from Radiochemical Centre, Amersham, England.

\section{REFERENCES}

Catt, K. J., Dufau, M. L. \& Tsuruhara, T. (1971) Studies on a radioligand-receptor assay system for luteinizing hormone and chorionic gonadotropin. 7. clin. Endocr. Metab. 32, 860.

Caulson, P., Liu, T-G., Morris, P. \& Gorskr, J. (1972) Interaction of LH with the ovary. In: Gonadotropins. p. 227. Eds. B. B. Saxena, C. G. Beling and H. M. Gandy. Wiley-Interscience, U.S.A.

Danzo, B. J., Midgley, A. R., JR \& Kleinsmith, L. J. (1972) Human chorionic gonadotropin binding to rat ovarian tissue in vitro. Proc. Soc. exp. Biol. Med. 139, 88.

de Kretser, D. M., Catt, K. J., Burger, H. G. \& Smith, G. C. (1969) Radioautographic studies on the localization of ${ }^{125}$ I-labelled human luteinizing and growth hormone in immature male rats. 7. Endocr. 43, 105.

de Kretser, D. M., Gatt, K. J. \& Paulsen, C. A. (1971) Studies on the in vitro testicular binding of iodinated luteinizing hormone in rats. Endocrinology, 88, 332.

Eshrol, A. \& Lunenfeld, B. (1968) Fate and localization of iodine-labelled HCG in mice. In: Gonadotropins, p. 187. Ed. E. Rosenberg. Geron-X Inc., Los Altos.

Espeland, D. H., Naftolin, F. \& Paulsen, C. A. (1968) Metabolism of labelled ${ }^{125}$ I-HCG by the rat ovary. In: Gonadotropins, p. 177. Ed. E. Rosenberg. Gerox-X Inc., Los Altos.

Figarova, V., Presl, J., Wagner, V. \& Horsky, J. (1970) Target organs of ${ }^{131}$ I-chorionic gonadotropin in immature female rat. Experientia, 26, 1017.

Greenwood, F. C., Hunter, W. M. \& Glover, J. S. (1963) The preparation of ${ }^{131}$ I-labelled human growth hormone of high specific radioactivity. Biochem. 7. 89, 114.

Gusdon, J. P., JR, Leake, N. H., Van Dyke, A. H. \& Atkins, R. J. (1970) Immunochemical comparison of human placental lactogen and placental proteins from other species. Am. F. Obstet. Gynec. 107, 441 . 
Josimovich, J. B. \& BRANDE, B. L. (1964) Chemical properties and biological effects of human placental lactogen (HPL). Trans. N.Y. Acad. Sci. 27, 161.

LEE, C. Y. \& RYAN, R. J. (1971) The uptake of human luteinizing hormone (hLH) by slices of luteinized rat ovaries. Endocrinology, 89, 1515.

Lefkowitz, R. J., Roth, J., Pricer, W. \& Pastan, I. (1970) ACTH-receptors in the adrenal: specific binding of ACTH ${ }^{125} \mathrm{I}$ and its relation to adenyl cyclase. Proc. natn. Acad. Sci. U.S.A. 65, 745.

LeIDENBERger, F. \& Reichert, L. E., JR (1972) Studies on the uptake of human chorionic gonadotropin and its subunits by rat testicular homogenates and interstitial tissue. Endocrinology, 91, 135.

Lowry, O. H., Rosebrough, N. J., FARR, A. L. \& Randall, R. J. (1951) Protein measurement with the Folin phenol reagent. J. biol. Chem. 193, 265.

Means, A. R. \& Vaitukaitis, J. (1972) Peptide hormone "receptors": specific binding of ${ }^{3} \mathrm{H}-\mathrm{FSH}$ to testis. Endocrinology, 90, 39.

Midgley, A. R., JR (1966) Radioimmunoassay: a method for human chorionic gonadotropin and human luteinizing hormone. Endocrinology, 79, 10.

Moudgal, N. R., Moyle, W. R. \& Greep, R. O. (1971) Specific binding of luteinizing hormone to Leydig tumor cells. 7. biol. Chem. 246, 4983.

Pastan, I., Roth, J. \& Macchia, V. (1966) Binding of hormone to tissue: the first step in polypeptide hormone action. Proc. natn. Acad. Sci. U.S.A. 56, 1802.

Rodbell, M., Krans, H. M. J., Pohl, S. L. \& Birnbaumer, L. (1971) The glucagon-sensitive adenyl cyclase system in plasma membranes of rat liver. III. Binding of glucagon: method of assay and specificity. 7. biol. Chem. 246, 1861.

Saxena, B. N. 1971) Protein-polypeptide hormones of the human placenta. Vitams Horm. 29, 95.

Sheth, A. R., Midgley, A. R. \& Niswender, G. (1973) Prolactin binding to sheep corpora lutea in vitro. Biol. Reprod. (in press). 